УДК 7.78.08;784.1;784.4

Ганна Василівна Карась, доктор мистецтвознавства, професор, ДВНЗ «Прикарпатський національний університет імені Василя Стефаника»,

Івано-Франківськ, Україна, e-mail: karasgukr.net, ORCID: 0000-0003-1440-7461

\title{
ІСТОРИКО-ГЕРОЇЧНИЙ ЕПОС УКРАЇНЦІВ НА СУЧАСНІЙ ЕСТРАДІ В ІНТЕРПРЕТАЦІЇ ТАРАСА ЖИТИНСЬКОГО
}

\begin{abstract}
Анотація. Представлення історико-героїчного епосу українців на сучасній естраді $\epsilon$ поодиноким явищем, тому метою нашого дослідження $є$ висвітлення цієї проблематики у творчості рок-музиканта, автора-виконавця Тараса Житинського. На основі звукозаписів співака, особистого спілкування 3 ним, музичної критики та публіцистики, які $є$ джерельною базою дослідження, зроблена спроба узагальнення творчого доробку митця в цьому напрямку.

Методологія дослідження передбачала використання міждисциплінарного, конкретно-історичного, культурологічного та акмеологічного підходів, які допомагають розглянути представлення українського історико-героїчного епосу на сучасній естраді у творчості одного виконавця в динаміці та різновидах. Міждисциплінарний підхід зумовив звернення до історії України, музичної фольклористики, естрадознавства; конкретно-історичний підхід застосовано для дослідження історії створення пісень та історичних подій, відображених у них; культурологічний підхід допомагає з'ясувати місце i значення історико-героїчного епосу українців для розвитку сучасної естради, патріотичного та естетичного виховання слухачів; акмеологічний підхід спрямовує дослідження
\end{abstract}


мистецької діяльності Т. Житинського в динаміці, виокремлення значення його самовдосконалення та самореалізації для творчого розвитку.

У дослідженні подано історію створення і зміст творів історико-героїчного плану, які виконує Т. Житинський, здійснена їх класифікація, а також виокремлено різностильові виконавські манери, притаманні співакові (автентичний чоловічий гуртовий спів у народному стилі; академічна манера; стилі «кантрі», «фольк-рок», «рок-н-рол», «шансон», ліричний бардівський спів). Творчий процес виконавця триває вже 3 десятки років. Еволюція митця зумовлена самовдосконаленням, постійним пошуком нових (забутих) пісень, їх презентуванням широкій публіці. Багатогранність таланту Т. Житинського представлена використанням різних виконавських манер, володінням інструментом, композиторським хистом, дослідницьким пошуком, менеджерськими якостями.

Ключові слова: історико-героїчний епос, українська естрада, пісня, виконавські стилі, музична культура, фолькорієнтація, співак Тарас Житинський

Вступ. Статтю присвячено представленню історикогероїчного епосу українців у творчості сучасного митця Тараса Житинського. Актуальність дослідження обумовлюється потребою глибшого осягнення трансформації українського фольклору на сучасній естраді.

Постановка проблеми. Висвітлюється широкий шар побутування історико-героїчного епосу на сучасній естраді, який $€$ вагомою складовою української народної музичної творчості та основою сучасних інтерпретацій. Він тісно пов'язаний із процесом формування українського народу у XIIIXIV ст., який відбувався в час боротьби проти монголо-татар, а потім - татар i турків. А. Іваницький твердить: «Численні жертви, що їх приносив народ впродовж століть у боротьбі за 
волю, підтримували стійкий інтерес до трагіко-героїчного епічного стилю, який дістав вищого розвитку у думах» [5, c. 126]. 3 того часу до наших днів ця вагома частина українського музичного фольклору не тільки розвивається у новотворах XX ст., а й зазнає трансформації, інколи навіть реінкарнації, у прочитанні сучасних естрадних виконавців, одним $з$ яких є Тарас Житинський.

Аналіз останніх досліджень і публікацій. Історія розвитку українського музичного фольклору висвітлена у праці А. Іваницького [5], витоки та інтонаційні складові української пісенної естради - у дослідженні Т. Рябухи [9], взаємопроникнення і синтез української естрадної музики i фольклору - у праці В. Тормахової [10]. А. Фурдичком здійснено комплексне дослідження процесів фольклоризму у пісенно-музичному мистецтві України (к. $\mathrm{XX}-$ поч. XXI ст.) [11]. Поряд із іншими аспектами, автор аналізує становлення та розвиток поп-фольк гілки української естради та iii основних виконавців, а також української альтернативної музики. Однак означена нами проблематика, як і постать Т. Житинського, не висвітлена у цих дослідженнях.

У статтях та інтерв'ю О. Бас [1], Л. Зьоли [4], О. Павлова [7], В. Підгайної [8] розкриваються окремі аспекти життєтворчості Т. Житинського, невеликий огляд здобутку виконавця знаходимо у нарисах О. Свтушенко [2]. Опис творів, які ввійшли до CD-альбому виконавця (рис.1), здійснений нами у передмові до нього [6].

Мета дослідження - висвітлити представлення Тарасом Житинським історико-героїчного епосу українців на сучасній естраді.

Виклад основного матеріалу. Народна пісенна творчість українців живить усі види й жанри музики, в тому числі й естрадну. Науковці виокремлюють певні ознаки фольклору, що можуть адаптуватися до особливостей останньої: інтонаційно-мотивні, метро-ритмічні; мелодична орнаментика, 
вокалізація голосних, лади; особливості типів багатоголосся; квадратно-симетричні побудови та інші [11, с. 178-179]. В. Тормахова наголошує: «Фольклор споріднений із джазовою, рок- і поп-музикою через загальні ознаки: колективність, анонімність, імпровізаційність творчості, незакріпленість, варіантність трактувань того самого твору» [10, с. 8]. Останніми часами в мистецтвознавстві утвердилось поняття фольк-орієнтації: «Це збірна категорія, що формує орієнтацію не лише на фольклор, а й на весь арсенал етномистецьких пріоритетів - образів, особливостей стилю, інтонацій, які виконавці, аранжувальники, композитори та поети-пісняри зуміли оформити в окремий потужний напрям» [11, с. 179]. Процес фольк-орієнтації притаманний українській естраді 3 1970-1980-х pр., а точкою відліку можна вважати творчість В. Івасюка, яка «...у своїй глибинній основі сформована на фольклорних джерелах» [11, с. 179]. Український пісенний фольклор є у репертуарі багатьох естрадних співаків.

На зламі XX-XXI ст. фольк-орієнтація зумовила зародження фольк-альтернативи, «...що поєднує всі можливі варіації модерної та постмодерної електронної музики 3 автохтонними предковічними смислами народного мелосу» [11, c. 189].

Серед виконавців, творчості яких притаманна і фолькорієнтація, i, частково, фольк-альтернатива - український рокмузикант, автор-виконавець Тарас Житинський. Він називає себе пілігримом, адже мандрує все своє життя, - об’їздив півсвіту, а з сер. 1990-х рр. живе на 2 країни - Україну й Велику Британію. О. Свтушенко писав: «Що не кажіть, а гени - велика річ. Народжений у родині репресованих вояків УПА в далекій Карагандинській області Тарас Житинський лише у 1981-му зміг повернутися на Батьківщину - у місто Івано-Франківськ» [2, с. 105-106]. Здобувши освіту на музично-педагогічному факультеті Івано-Франківського педінституту ім. В. Стефаника, він завойовує важливі перемоги: дипломант джаз-фестивалю 
«Кришталевий лев» (1989р.), третя премія на фестивалі «Червона рута» (1991), аналогічна премія на «Слов'янському базарі» (1992 р.), із групою «Скала» - переможець рокфестивалю «Тарас Бульба» (1994р.), володар Гран-прі фестивалю «Повстанським плаєм» (2007 р.).

Святкування 50-ліття створення Української повстанської армії (УПА) у 1992 р., в якому Т. Житинський брав активну участь, спрямувало його творчість у руслі національнопатріотичної пісні: «Саме там розкрилися у повній мірі дивовижна харизма, сильний голос і вкрай експресивна манера виконання співака - три складові, що скрізь, де б не виступав, приносили йому успіх» [2, с. 106].

Перебравшись до Лондону, Тарас у вільний від важкої праці час віддає себе музичній творчості, контактує 3 українською діаспорою, створює гурт «Земляки». О. Свтушенко підкреслює: «Головними “кониками” репертуару Житинського були козацькі пісні, історичні думи та пісні УПА. Відростивши собі на голові справжнього оселедця, він став схожим на вільного козака в екзилі. Це був план навернення українців до рідного коріння. Тарас довів, що, живучи в іншій країні, можна розвивати власну культуру і бути цікавим для місцевої публіки. Тому й не дивно, що Тарас в Англії таки має прихильників серед англосаксів» [2, с. 106].

Як засвідчує період Незалежності України, до рідного коріння необхідно навертати українців і на рідній землі. 3 цією метою, Т. Житинський багато концертує Україною, записує альбоми: у 1990-х рр. - «Чорний лебідь», «Ва-банк», «Синьожовта ріка», у 2009 р. - «Козацькі балади» та «Їхали батяри». Своєрідним узагальненням творчості, проектом усього життя $€$ альбом «Історія України в піснях XVII-XX століть» (2016р.) своєрідна антологія пісень української боротьби й величі духу, до якої ввійшли майже 60 творів різних жанрів, - від дум та історичних пісень до сучасних новотворів із 4 альбомів [3]. Свою місію виконавець сформував так: «Колись давно, в 
Стародавньому Римі, імператор Троян казав, що народ можна знищити, не обов'язково воюючи з армією чи руйнуючи храми, можна просто знищити його історію. Ми зараз знову підіймаємо цю історію, яку для нас зберіг наш народ. Він цю свічку проніс крізь століття, і ми так само іiі несемо, ця свічка ніколи не загасне. Піснями ми повертаємо українську історію» [8]. Тепер співак працює над п'ятим випуском альбому, до якого долучить ще 15 нових пісень.

T. Житинський направду пропонує зацікавленому слухачеві історію рідного народу продовж останніх 5 століть у піснях, які спробуємо проаналізувати.

Найдавнішими за походженням є козацькі пісні, які виникли у XV-XVI ст. і найбільше увібрали в себе історичні реалії своєї доби. Маючи у своїй основі реальні факти і явища (боротьба 3 турецько-татарськими нападниками, перемоги i поразки козацького війська, чужинська неволя, рабство і т. п.), козацькі пісні передусім творять ліричний образ козака типового представника Запорізької Січі, відтворюють його внутрішній духовний світ, передають романтику козацької волі. У них степові лицарі-запорожці зображені оборонцями рідного краю. Історичні nicнi - поширений жанр героїчного поетичного епосу українського народу. Це - ліро-епічні твори про конкретні чи типові історичні події та процеси, відомих історичних осіб, чиє життя і вчинки пов'язані з подіями суспільно-політичного життя, в яких відтворено дух певної історичної епохи. Історична пісня, $з$ одного боку, є продуктом розвитку ліричної пісні, а, 3 ншого - належить до епічної поезії.

Жанр козацької історичної пісні представлений у доробку Т. Житинського багатьма творами. Так, пісня «Ой, на горі там женці жнуть» - про одного 3 найвидатніших полководців Європи, державного діяча та дипломата - Петра Конашевича-Сагайдачного (1570-1622рр.), який не програв жодної битви ні на суші, ні на морі. Хотинська битва стала останньою для гетьмана - від численних ран, отриманих на полі 
бою, він помер у Києві. Пісня «Ой полечко, поле» передає картину смерті двох козаків - з багатої і бідної родин, і відмінне ïх пошанування суспільством. Авторство пісні «Ой, горе тій чайці» приписують Івану Мазепі (1639-1709 рр.) - українському державному i політичному діячеві, гетьману Лівобережної України та Війська Запорозького обох берегів Дніпра, меценату української культури. Як високоосвічена людина, І. Мазепа був поетом, музикантом (грав на бандурі). Пісню «Ой, горе тій чайці» вважають не тільки улюбленою піснею гетьмана, а його авторською. За жанром - це пісня-символ, тужливий плач за долею поневоленої України. «Гей, розвивайся, та сухий дубе» належить до пісень про майбутній похід запорожців. Пісня «Ізза гори, із-за кручі» присвячена ватажку запорожців, полковнику Данилу Нечаю, який наклав головою, б'ючись iз поляками у 1651 р. «За Сибіром сонце сходить» - пісня про Устима Кармелюка, який уславився в 1830-х рр. на Поділлі, та гайдамаччину. Одним із найкращих творів про народного ватажка опришків Олексу Довбуша (1700-1745 рр.), який діяв із своїм загоном на Прикарпатті, Закарпатті та Буковині, є історична пісня «Ой, попід гай зелененький», яка сприймається як своєрідний документ про його загибель. Морська козацька пісня «Гей, нумо, хлопці, до зброї» передає козацьку відвагу, щиру християнську віру у перемогу й опіку святих (святого Юрія та Пречистої Матері Божої Марії). Козацька лірична пісня «Там на горі крута вежа» була поширеною в Галичині, зокрема i середовищі Українських Січових Стрільців (УССів), а також воїнів УПА. Українська морська козацька пісня «Ой, по синьому морю», про визволення козаків із турецької неволі, актуалізована в репертуарі не тільки сучасних бандуристів, а й бардів. Жартівлива лірична козацька пісня «Ішов козак потайком» повна оптимізму, бадьорості, виконується співаком у стилі «рок-н-рол», а лірична «Там, на ставі» - a cappella в стилі народного гуртового співу. 
3 II пол. XVIII ст. складаються рекрутські та солдатські пісні, оскільки вводилась обов'язкова військова служба як у Росії (східні землі України входили до ії складу), так і в Австрії (згодом - Австро-Угорщині), до складу якої входили західні землі України. До них примикає солдатська пісня-вальс XIX ст. з Волині «В неділю пораненьку».

Думи - це народні епіко-ліричні пісенні твори героїчного, рідше соціально-побутового змісту. Вони належать до найвизначнішої частини українського народного епосу. Думи виникли в XVI ст. і продуктивно розвивалися впродовж 3 століть. Походження жанру пов'язане з посиленням боротьби українського народу проти іноземного поневолення та феодально-кріпосницького гніту. Для захисту рідної землі в цей час формується могутня сила самооборони - козацтво. Життя козаків та їх боротьба складають основну вісь героїкоромантичних оповідей дум XVI ст. Другу групу складають думи XVII-XVIII ст. про визвольну боротьбу українського народу 1648-1654 pp. Основна тематика дум породжена епохою безперервної всенародної боротьби з іноземними загарбниками українських земель. У них оповідається про подвиги народу чи його окремих представників-героїв, що виступили на захист своєї Батьківщини від навали чужинців-поневолювачів, часто оспівується героїчна смерть воїна в цій боротьбі. Суттєвою рисою дум $\epsilon$ імпровізаційність. Виконавець дум має творчу свободу у їх донесенні до слухача. Думи виконувалися мандрівними співцями-рапсодами, кобзарями та лірниками, тобто спів звучав у супроводі кобзи, бандури або ліри (рідше).

Т. Житинський бере до свого репертуару кілька дум, ставлячись до них дуже трепетно, - виконує автентично, дотримуючись збережених оригіналів. Козацька дума «Ой, у 1791 році» - з літопису чорноморського козацького війська, що відображає перший період інтенсивної російської колонізації Півдня України. ІІї зміст передає історичні події, коли російська цариця Катерина II видала наказ про виселення козаків на річку 
Кубань. На CD записано 2 варіанти цієї думи, які виконуються автентичним гуртовим співом без супроводу (тут співак використовує студійний запис, самостійно виконуючи всі партії поступово, і зводячи їх до багатоголосого варіанту). У козацькій думі «Гомін, гомін по діброві» мати лякає сина бідою, тільки б він не пішов на Запоріжжя, адже вільне, веселе та славне лицарське життя запорожців приваблювало на Січ силу народу. Козацька дума на слова I. Котляревського «Ой, віє ж вітер»діалог козака й вітру про волю. «Гей, літа орел» - дума про запорізького козака Максима Залізняка, який очолив велике народно-визвольне повстання, відоме під назвою «Коліївщина» (почалося навесні 1768 р.). Розбивши ворога, гайдамаки оголосили Україну вільною і обрали гетьманом М. Залізняка. Польський король С. Понятовський у змові 3 російською царицею Катериною II руками генерала Гур'єва виманили всю козацьку старшину на нараду, де ї арештували, а військо розбили. Залізняка було заслано до Сибіру, а Гонту видано полякам, які його стратили.

3 піднесенням національно-патріотичної свідомості українців Галичини, у 1900 р. лідер Русько-Української Радикальної партії К. Трильовський ініціюе створення протипожежно-спортивних товариств під назвою «Січ». Ця назва означала поворот у свідомості від побутово-практичного виховання до наголосу на славетній українській історії, на традиціях Запорізької Січі. У 1911-1914 рр. воєнізовані товариства «Січ» та «Сокіл» набувають антиросійської орієнтації. 3 початком Першої світової війни (1914р.) утворюється військове формування УСС, яке входило до складу австро-угорської армії і брало участь у боях із російською армією. Після краху Австро-Угорщини галицькі УССи влилися до складу Української Галицької Армії Західно-Української Народної Республіки. В середовищі УССів виникли стрілецькі $n i c н i$, які стали новотворами XX ст. Хоча вчені розглядають їх у системі усно-писемної культури і часто ці твори мали авторів, 
проте для них характерна поглиблена фольклоризація. Тематика стрілецьких пісень надзвичайно широка, а провідними є зразки героїко-патріотичної, бойової та ліричної тематики.

Звернення Т. Житинського до стрілецької пісні теж не випадкове, адже його дід, Василь Онуфрійович Стефанів, воював у підрозділі УССів під керівництвом полковника Самокиша у військах С. Петлюри. Пісня «Як 3 Бережан до Кадри» написана письменником, хорунжим легіону УСС та УГА Р. Купчинським у жовтні 1916 р. В основі мелодії, як вважав композитор Я. Ярославенко, лежить мотив народної пісні «Weseło, bracia, weseło...» із записів В. Залеського. Пісня фольклоризувалася в середовищі стрілецтва і стала загально улюбленою та однією 3 найпоширеніших стрілецьких пісень. «Розпрощався стрілець» належить до поширених і популярних пісень УССів. У радянські часи вона піддалася фальсифікації. Мелодію цього стрілецького реквієму більшовиками було запозичено буквально. Вони, переробивши текст i пристосувавши його до тогочасних ідеологічних потреб, використали для створення начебто революційної пісні «Там, вдали за рекой», хоч такої пісні в роки громадянської війни (1918-1920рр.) у російській більшовицькій армії не існувало. Слова та мелодія пісні «Гей, там, на горі, Січ іде» написані К. Трильовським із нагоди першого Січового свята 6 червня 1902 р. у м. Коломия (нині Івано-Франківської обл.). Ця пісня стала гімном січовиків, оскільки іiі патріотичний зміст цілком відповідав ідейним переконанням стрілецтва. Масовий характер виконання пісні в Галичині протягом I десятиріччя XX ст. i пізніше, зумовили iї довголіття. «Гей, на горі на Маківці» належить до історичних пісень УССів, оскільки присвячена бою січових стрільців із москалями на горі Маківка, що вівся 29 квітня -2 травня 1915 р. Світла, хоч кривава, перемога УССів на цій горі, усталила їх безсмертну славу. Тематично пісня має соборницький характер, оскільки вказує на синьо-жовтні прапори у Києві, тобто засвідчує акт Злуки УНР та ЗУНР. У 
1990-х рр. вона актуалізована у сучасних варіантах, що $\epsilon$ свідченням нових форм поширення фольклорних текстів, зокрема стрілецьких пісень. Пісня УССів «Там, за небокраєм» інтерпретується виконавцем у стилі «рок», популярна лірична пісня «Ой, там у Львові» - у стилі «кантрі», а пісня «Гей ви, хлопці» осучаснена ритмами XX ст. Пісня «Гей-гу гей-га» (музика i слова Т. Чача-Крушельницького) - єдина 3 жанру пластових пісень («Пласт» - національна скаутська організація українців, заснована в 1911 р., заборонена польською, німецькою і радянською владою. У свій час учасниками Пласту були такі видатні українці як С. Бандера, Б. Гаврилишин, Р. Шухевич та ін.

Пісні національно-визвольних змагань початку XX cm., які співали вояки армії С. Петлюри чи козаки Н. Махно, належать до привласнених росіянами. Так, «Любо, братці, любо» - пісня козаків батька Махна, основу до якої вони взяли 3 козацької народної пісні Кубанських козаків. Цю пісню любив співати і сам Н. Махно. Т. Житинський каже: «Нічого не маючи проти варіантів різними мовами, де люди гарно виконують цю пісню, поміж тим горджусь що БОГ поміг мені знайти i заспівати цю пісню, де б'ється серце, де живе душа. Велика сила духу, козачий характер мого народу» [3]. Він розповідає, що українська версія пісні була записана етнографом Олександром Грибом в 1997 р. на півдні України. Тобто саме там, де у давнину гуляли козаки, а майже сто років тому - загони Н. Махно. Гриб подарував Тарасові касету, на якій той почув розмову з літнім чоловіком, який розповів про те, що його дід воював у військах батька Махна і співав цю пісню саме українською мовою. «В інтернеті ця пісня викликає десятки тисяч переглядів і сперечань. Бо вона також відома і російською мовою. Мені не відомо, хто іiі першим заспівав, але я напевно знаю, що у батька Махна пї співали українською», каже T. Житинський [7]. Козаки батька Махно співали пісню «Ех, яблучко». Маловідомий текст «Ой, ти батьку, степ широкий 
мій» ватажка селянського повстанського руху на півдні України у 1918-1921 pр., анархіста Нестора Махно сповнений воєнної романтики, отримує сучасну інтерпретацію у творчості Т. Житинського, який написав музику до нього. Махно уособлює тип народного героя, народженого вибухом революційної стихії, а його поезія передає єднання зі степом символом вольниці.

У часи Другої світової війни Організація Українських Націоналістів розпочинає боротьбу спершу проти німецьких окупантів, а від 1944 р. - проти більшовиків. Рух опору на чолі 3 УПА, який був масовим, породив виникнення ще одного пласту народної творчості - повстанських пісень. У них відображалися нові історичні реалії та умови боротьби. За стилістикою частина повстанських пісень виразно зближається 3 народноромансовим струменем фольклору. Обидва останні жанри (стрілецька і повстанська пісня) в часи радянської влади були забороненими як для вивчення, так і для популяризації. Проте вони збереглися в народній пам'яті в Україні та в діаспорі, а 3 часу проголошення незалежності України у 1991 р. активно введені до наукового обігу, концертного виконання.

Цей жанр належить до улюблених у творчості Т. Житинського. Популярна пісня воїнів УПА «Завтра в далеку дорогу» відображає долю повстанця, зокрема прощання 3 родиною та коханою. Лірико-патріотична тематика зумовлює популярність пісні і в наші дні. «Вже вечір вечоріє» належить до популярних повстанських пісень, які відображають військовий побут: запеклий бій, поранення, незламний дух повстанців. Чіткий маршовий ритм, мажорна тональність та рухливий темп сприяють створенню яскравого музичного образу. За образним змістом пісню «Там, під Львівським замком» можна вважати своєрідним реквіємом, оскільки в ній передано прощання матері 3 убитим сином-партизаном. Використання рівномірної розлогої мелодії сприймається як своєрідна «колискова» згорьованої матері. Виразний патріотичний мотив та жаль за полеглими 
повстанцями спопуляризували пісню в Галичині настільки, що вона часто звучить у побуті до наших днів. «Марш дивізії «Галичина», яка була сформована у 1943 р., а під кінець війни стала Першою Українською Дивізією Української Національної Армії, передає основну мету дивізії - боротьба за вільну незалежну Україну. Автором слів і музики $є$ ректор собору Святої Софії в Римі, отець-доктор Іван Музичка - колишній воїн дивізії, який навчався у Вищому музичному інституті ім. М. Лисенка у Львові, диригував хорами, викладав клас скрипки в учительській семінарії в Рогатині, грав у дивізійному оркестрі.

Авторські твори у репертуарі Т. Житинського теж добираються в контексті історико-героїчної тематики. Так, пісня «Курінний» (слова i музика О. Веремчука) - про події 1920-х рр., воїнів армії УНР, які вели відчайдушну боротьбу за незалежність України. Виконавець присвячує ії полковнику Армії УНР П. Болбочану. Авторська пісня Т. Житинського «Синам УПА», яка присвячена воїнам УПА, мелодично наближена до народної пісні, за стилем виконання та аранжування - до рок-музики. Пісня «Мій друже, Ковалю» (музика Ю. Галича, слова М. Матоли) - про героїчну боротьбу вояків УПА. Т.Житинський здійснив український переклад відомої пісні В. Висоцького «На братських могилах» про братські могили після Другої світової війни і виконує ії в стилі автора. Емігрантська пісня-танго «Прощай, Україно» (автор О. Смик) передає тужливі хвилини прощання воїнів з Україною. Ще один твір О.Смика, «Отаманша Маруся» - про шістнадцятирічну гімназистку Олександру Соколовську, яка після загибелі братів, повстанських отаманів, стала на чолі тисячного війська у 1918-1919 pр. Пісня «Пане Симоне» (музика i слова О. Смика) присвячена головному отаману УНР С. Петлюрі.

Авторська пісня Т. Житинського «Мені сьогодні було 20 літ» належить до творів про введення у 1979 р. радянських 
військ в Афганістан, примусову участь молодих українських вояків у війні, яка тривала до 1989 р. і на фронтах якої полягло 3,5 тис. українців. Пісня УНА-УНСО «Хорватський марш» про воєнні події на Балканах складена на відому мелодію італійських партизан «Белла, чао», є однією 3 найвідоміших антифашистських міжнародних пісень. Ї̈̈ виконують різні рухи спротиву, варіюючи літературний текст, додаючи щось своє. Так поступили й українці. В основу своєї діяльності УНА поставила ідею Нації. Організація пройшла бойовий вишкіл, як організована сила брала участь у 4-х сучасних війнах. Лірикопатріотичний твір сучасного композитора І. Іванціва «Ой, рекруте» написаний на текст О. Смика в стилі авторських пісень і побудований на діалозі рекрута та його коханої.

Національний дух українців не тільки не згасав у найтяжчі історичні часи, але на поч. XXI ст. явив усьому світу свою гідність і незламність. Нещодавно розв'язана Росією війна проти України спонукає не тільки до опору агресору, але й до творення нових пісень, які допомагають українцям вистояти i боротися за свою свободу. Т. Житинський виступає на Сході України, співає на передовій, для «Правого сектору», для XI батальйону, на полігонах, для «Добровольчого українського корпусу», у Львівському військовому шпиталі, у шпталях Києва. Його мета - співом і піснями об'єднати Україну.

Авторські твори Т. Житинського «Майдан 2014»- пісня Революції Гідності, «Залізна бригада» (на слова Р. Семісала), яка присвячена захисникам Донецького аеропорту українським кіборгам, авторський твір Живосила Лютого «Мчать козаки», яка присвячена всім небесним сотням України, - це відгук на історичні події останнього часу.

Отже, творчість Т. Житинського припадає на III період розвитку української естради, який, на думку Т. Рябухи, характеризується «...ренесансом сольної естрадної пісні, переважно ліричної, і містить спеціальну орієнтацію на національно характерні лексичні елементи» [9, с. 181]. Така 
орієнтація спрямовує до пізнання національної народної творчості. В. Тормахова виокремлює такі типи взаємозв'язків фольклору з естрадною музикою: 1) обробки народних пісень; 2) цитування музично-фольклорного матеріалу; 3) створення оригінальних композицій на фольклорній основі - інтонаціях, звукорядах, текстах, прийомах виконання; 4) сплав національної манери виконання 3 інофольклорною (застосовується в джазі, поп-музиці) [10, с. 10]. Усі вони притаманні творчості Т. Житинського. Виконання всіх вище названих творів таке ж різноманітне, як і жанри, в яких вони написані. Ми чуємо спів чистого оксамитового баритона Тараса без супроводу (у старовинній думі), під власний супровід гітари та різного роду інструментальних ансамблів. Приваблюють різностильові виконавські манери співака: автентичний чоловічий гуртовий спів у народному стилі (тут Т. Житинський здійснює студійний запис свого голосу, виконуючи всі партії почергово) при виконанні дум та козацьких пісень; академічну манеру співак застосовує у дуеті з дочкою, Іриною Житинською, оперною співачкою, примадонною Вроцлавсьої опери, виконуючи пісню «Ой, рекруте»; стиль «кантрі» (вплив канадських та американських гуртів української діаспори) виконавець використовує для стрілецьких та повстанських пісень («Вже вечір вечоріє», «Там на горі крута вежа», «Ой там у Львові»); в стилі фольк-рок виконується пісня «Ішов козак потайком», а пісні «Синам УПА», «Там за небокраєм», «Залізна бригада», «Мчать козаки» мають яскраве забарвлення рок-н-ролу (Т. Житинський вважає, що основний вплив у цьому жанрі на нього справили британські рок-гурти «Deep Purple» та «Pink Floyd», українська рок-група «Кому вниз»); ліричний бардівський спів притаманний більшості його творів; не уникнув виконавець і шансону (в цьому напрямі виконується пісня «Отаманша Маруся»). Основним інструментом, який використовує виконавець для супроводу, $є$ акустична гітара, якою він добре володіє. Для творів в стилі рок Т. Житинський 
використовує електрогітари, ударні інструменти, трубу, синтезатори, для пісень у фольк-стилі - бандуру, сопілку, скрипку. Як аранжувальник багатьох пісень Т. Житинський застосовує імпровізацію, змінює їх ритміку і мелодику, додає власні вставки. Для створення художнього образу козаківмахновців у пісні «Ех, яблучко» застосовано імітацію скрипу возів, звучання гармошки, свист.

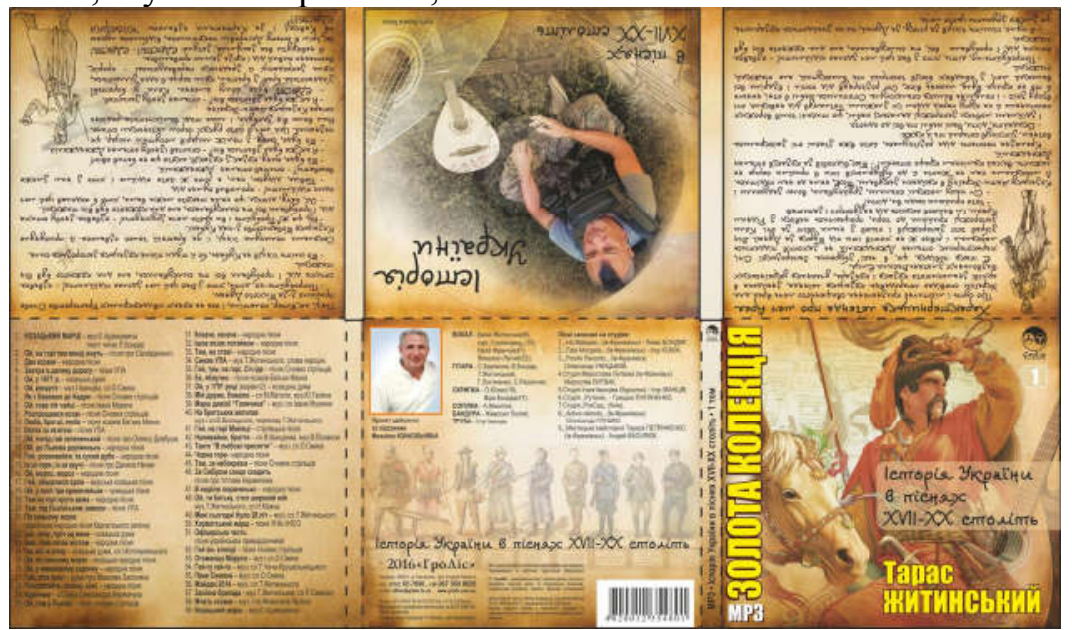

Рис. 1. Диск Т. Житинського «Історія України в піснях XVIIХХ століть»

Висновки. Т. Житинського називають бардом, рокером, сучасним кобзарем, проте виконавець сам себе відносить до рокерського цеху. Він підкреслює про такі явні напрямки свого виконавства: рок-музика, поп-музика i шансон, український фольклор. «Для мене стилі вже давно не важливі, для мене головний зміст» [1]. Творчий процес виконавця триває вже 3 десятки років. Еволюція митця зумовлена самовдосконаленням, постійним пошуком нових (забутих) пісень, їх представленню широкій публіці. Якщо на початковому етапі це були окремі твори, то впродовж 
останнього десятиліття чітко сформувався великий цикл героїчно-патріотичної тематики. Багатогранність таланту T. Житинського представлена використанням різних виконавських манер, володінням інструментом, композиторським хистом, дослідницьким пошуком, менеджерськими якостями. Як виконавець він використовує точне фольклорне цитування без змін, як композиторвиконавець - здійснює аранжування та обробки українських народних пісень у різних стилях і манерах, які завдяки його «...творчому переосмисленню отримують нове дихання, стають ближчими до народу, тобто повертаються на своє питоме природнє місце - у свідомість українців» [11]. Т. Житинський не $€$ поп-виконавцем i представником шоу-бізнесу, а тому не збирає стадіони чи величезні концертні зали захопленої публіки. Однак важливо, що пісні Тараса торкають душу, хвилюють почуття, спонукають задуматись над долею України i не залишать байдужим кожного, хто слухатиме їх. А таких, готових слухати його пісні, є багато і це ті, кого хвилює історія і майбутнє України.

\section{Література}

1. Бас О. Для мене стилі вже давно не важливі, для мене головний зміст.

URL:https://kurs.if.ua/articles/taras_zhytynskyy_shche_ne_chas_dly a_ostannogo_tatu_21847.html/

2. Свтушенко O. Україна IN ROCK: статті та есеї. Київ: Грані-T, $2011.240 \mathrm{c}$.

3. Житинський T. Історія України в піснях XVII-XX століть. CD. Тернопіль: «ГроЛіс», 2016. (Серія «Золота колекція 1 МР3»).

4. Зьола Л. Украдені пісні повертає Україні бард Тарас Житинський. URL: https:/galychyna.if.ua/analytic/ukradeni-pisnipovertaye-ukrayini-bard-taras-zhitinskiy/

5. Іваницький А. Український музичний фольклор: підручник для ВНЗ. Вінниця: НОВА КНИГА, 2004. 320 с. 
6. Карась Г. Історія України в піснях XVII-XX століть: передмова до альбому: Житинський Т. Історія України в піснях XVII-XX століть. СD. Тернопіль: «ГроЛіс», 2016. (Серія «Золота колекція $1 \mathrm{MP} 3 »)$.

7. Павлов О. Лондонський козак Тарас Житинський. URL: https://www.dw.com/uk/\%D0\%BB\%D0\%BE $\% \mathrm{D} 0 \% \mathrm{BD} \% \mathrm{D} 0 \% \mathrm{~B} 4 \%$ D0\%BE\%D0\%BD\%D1\%81\%D1\%8C\%D0\%BA\%D0\%B8\%D0\%B 9-\%D0\%BA\%D0\%BE\%D0\%B7\%D0\%B0\%D0\%BA$\% \mathrm{D} 1 \% 82 \% \mathrm{D} 0 \% \mathrm{~B} 0 \% \mathrm{D} 1 \% 80 \% \mathrm{D} 0 \% \mathrm{~B} 0 \% \mathrm{D} 1 \% 81-$ $\% \mathrm{D} 0 \% \mathrm{~B} 6 \% \mathrm{D} 0 \% \mathrm{~B} 8 \% \mathrm{D} 1 \% 82 \% \mathrm{D} 0 \% \mathrm{~B} 8 \% \mathrm{D} 0 \% \mathrm{BD} \% \mathrm{D} 1 \% 81 \% \mathrm{D} 1 \% 8$ C\%D0\%BA\%D0\%B8\%D0\%B9/a-5713178

8. Підгайна В. Тарас Житинський: «Піснями ми повертаємо українську історію». URL: http://sumno.com/article/taraszhytynskyj-pisnyamy-my-povertajemo-ukrajin-1/

9. Рябуха Т. Витоки та інтонаційні складові української пісенної естради: дис. на здобуття наук. ступеня канд. мистецтвознавства. Харків, 2017. 203 с.

10. Тормахова В. Українська естрадна музика i фольклор: взаємопроникнення і синтез: автореф. дис. на здобуття наук. ступеня канд. мистецтвознавства. Київ, 2007. 21 с.

11. Фурдичко А. Український мелос на зламі тисячоліття: динаміка фольклорної традиції: монографія. Київ: Вид. центр КНУКiM, 2018. 316 c. 


\title{
Анна Васильевна Карась, доктор искусствоведения, профессор, \\ ГВУЗ «Прикарпатский национальный университет имени \\ Василия Стефаника», Ивано-Франковск, Украина, e-mail: karasg@ukr.net, ORCID: 0000-0003-1440-7461 \\ ИСТОРИКО-ГЕРОИЧЕСКИЙ ЭПОС УКРАИНЦЕВ НА СОВРЕМЕННОЙ ЭСТРАДЕ В ИНТЕРПРЕТАЦИИ ТАРАСА ЖИТИНСКОГО
}

\begin{abstract}
Аннотация. Представление историко-героического эпоса украинцев на современной эстраде - это единичное событие, поэтому цель нашего исследования - освещение этой проблематики в творчестве рок-музыканта, автора-исполнителя Tараса Житинского. На основе звукозаписей певца, личного общения с ним, музыкальной критики и публицистики, которые являются базой иточников исследования, сделана попытка обобщения творчества певца в этом направлении.

Методология исследования предусматривала
\end{abstract} использование междисциплинарного, конкретно-исторического, культурологического и акмеологического подходов, помогающих рассмотреть представление украинского историкогероического эпоса на современной эстраде в творчестве одного исполнителя в динамике и разных видах. Междисциплинарный подход обусловил обращение к истории Украины, музыкальной фольклористике, эстрадоведению; конкретно-исторический подход применен для исследования истории создания песен и исторических событий, отраженных в них; культурологический подход помагает рассмотреть место и значение историкогероического эпоса украинцев для развития современной эстрады, патриотического и эстетического воспитания слушателей; акмеологический подход направляет исследование 
творческой деятельности Т. Житинского в динамике, выделении значения его самосовершенствования и самореализации для творческого развития.

В исследовании поданы история создания и смысл произведений историко-героического плана, исполнявшихся T. Житинским, осуществелена их классификация, а также выделены разностилевые исполнительские манеры, присущие певцу (аутентичное мужское общее пение в народном стиле; академическая манера; стили «кантри», «фольк-рок», «рок-нролл», «шансон», лирическое бардовское пение). Творческий процесс исполнителя длится уже 3 десятилетия. Эволюция певца обусловлена самосовершенствованием, постоянным поиском новых (забытых) песен, их представлением широкой публике. Многогранность таланта Т. Житинского проявляется в использовании разных исполнительских манер, владении инструментом, композиторским мастерством, исседовательским поиском, менеджерскими качествами.

Ключевые слова: историко-героический эпос, украинская эстрада, песня, исполнительские стили, музыкальная культура, фольк-ориентация, певец Тарас Житинский

\author{
Hanna V. Karas, \\ DSc in Arts, Professor, \\ Vasyl Stefanyk Precarpathian National University, \\ Ivano-Frankivsk, Ukraine, \\ e-mail: karasg@ukr.net, \\ ORCID: 0000-0003-1440-7461
}

\title{
HISTORICAL AND HEROIC EPIC OF THE UKRAINIANS ON THE MODERN STAGE IN THE INTERPRETATION OF TARAS ZHYTYNSKY
}

\begin{abstract}
The presentment of historical and heroic epic of the Ukrainians on the modern stage is an isolated event, so the
\end{abstract}


purpose of our study is the coverage of this issue on the example of the creative work of the Ukrainian rock musician and singersongwriter Taras Zhytynsky. An attempt to generalize the artists' creative work in this regard involving the source base of the study specifically singer's sound recordings, face-to-face communication with him was made.

Survey methodology included the use of interdisciplinary, concrete historical, culturological, and acmeological approaches which help to consider the presentment of the Ukrainian historical and heroic epic on the modern stage in the creative works of a performer in its dynamics and varieties. The interdisciplinary involved the reference to the history of Ukraine, musical folklore, popular music studies. The concrete historical approach is used to investigate the song and corresponding event background, the culturological approach helps to find out the part and significance of the Ukrainians' historical and heroic epic for the development of the modern popular music, patriotic and aesthetic education of the listeners. The acmeological approach directs the study of the Taras Zhytynsky's artistic activity in dynamics highlighting the importance of his self-improvement and self-realization for his creative development.

The study presents and classify the background of performed by Taras Zhytynsky's works and their content in the historical and heroic plan. It also outlines the author's different genres performing manners (male authentic singing in folk style, academic style, country style, folk rock, rock and roll, chanson, bard singing). The author's creative career started more than 30 years ago. Selfimprovement, constant search for new and forgotten songs, the presentation of his works to wide audience promote the author's evolution. The versatility of Taras Zhytynsky's talent is represented by the use of different performance manners, instrumental technique, a composer's gift, researcher's inquiry, and managerial competence. 
Key words: historical and heroic epic, Ukrainian art of variety, song, performing manners, music culture, folk orientation, a performer Taras Zhytynsky

\section{References}

1. Bas, O. Dlia mene styli vzhe davno ne vazhlyvi, dlia mene holovnyi zmist [For me, styles have not been important for a long time, for me the main content] Available at: https://kurs.if.ua/articles/taras_zhytynskyy_shche_ne_chas_dlya_osta nnogo_tatu_21847.html/ [in Ukrainian].

2. Yevtushenko, O. (2011). Ukraina IN ROCK: statti ta esei [Ukraine IN ROCK: articles and essays]. Kyiv: Hrani-T [in Ukrainian].

3. Zhytynskyi, T. (2016). Istoriia Ukrainy v pisniakh XVII$\mathrm{XX}$ stolit [History of Ukraine in the songs of the XVII-XX centuries]. CD. Ternopil: «HroLis» (Seriia «Zolota kolektsiia 1 MP3») [in Ukrainian].

4. Zola, L. Ukradeni pisni povertaie Ukraini bard Taras Zhytynskyi [Bard Taras Zhytynsky returns the stolen songs to Ukraine]. Available at: https://galychyna.if.ua/analytic/ukradenipisni-povertaye-ukrayini-bard-taras-zhitinskiy/ [in Ukrainian].

5. Ivanytskyi, A. (2004). Ukrainskyi muzychnyi folklore [Ukrainian musical folklore]: pidruchnyk dlia VNZ. Vinnytsia: NOVA KNYHA [in Ukrainian].

6. Karas, H. (2016). Istoriia Ukrainy $\mathrm{v}$ pisniakh XVII-XX stolit: peredmova do albomu: Zhytynskyi $\mathrm{T}$. Istoriia Ukrainy $\mathrm{v}$ pisniakh XVII-XX stolit [History of Ukraine in the songs of the XVII-XX centuries: preface to the album: History of Ukraine in the songs of the XVII-XX centuries]. CD. Ternopil: "HroLis" (Seriia "Zolota kolektsiia 1 MP3") [in Ukrainian].

7. Pavlov, O. Londonskyi kozak Taras Zhytynskyi [London Cossack Taras Zhytynsky]. Available at: https://www.dw.com/uk/\%D0\%BB\%D0\%BE\%D0\%BD\%D0\%B4\% D0\%BE\%D0\%BD\%D1\%81\%D1\%8C\%D0\%BA\%D0\%B8\%D0\%B 
9-\%D0\%BA $\%$ D0 $\%$ BE $\%$ D0 $\%$ B $7 \% \mathrm{D} 0 \% \mathrm{~B} 0 \% \mathrm{D} 0 \% \mathrm{BA}-$ $\% \mathrm{D} 1 \% 82 \% \mathrm{D} 0 \% \mathrm{~B} 0 \% \mathrm{D} 1 \% 80 \% \mathrm{D} 0 \% \mathrm{~B} 0 \% \mathrm{D} 1 \% 81-$ $\%$ D0\%B6\%D0\%B8\%D1\%82\%D0\%B8\%D0\%BD\%D1\%81\%D1\%8 C\%D0\%BA\%D0\%B8\%D0\%B9/a-5713178 [in Ukrainian]. 8. Pidhaina, V. Taras Zhytynskyi: "Pisniamy my povertaiemo ukrainsku istoriiu" [Taras Zhytynsky: "With songs we return Ukrainian history"]. Available at: http://sumno.com/article/taraszhytynskyj-pisnyamy-my-povertajemo-ukrajin-1/ [in Ukrainian].

9. Riabukha, T. (2017). Vytoky ta intonatsiini skladovi ukrainskoi pisennoi estrady [Origins and intonation components of Ukrainian song variety]: dys. na zdobuttya nauk. stupenya kand. mystetstvoznavstva: Kharkiv [in Ukrainian].

10. Tormakhova, V. (2007). Ukrainska estradna muzyka i folklor: vzaiemopronyknennia i syntez [Ukrainian pop music and folklore: interpenetration and synthesis]: avtoref. dys. na zdobuttya nauk. stupenya kand. mystetstvoznavstva: Kyiv [in Ukrainian].

11. Furdychko, A. (2018). Ukrayinskyi melos na zlami tysyacholittia: dynamika folklornoyi tradytsiyi [Ukrainian melody at the turn of the millennium: the dynamics of folk tradition]. Kyiv: Vyd. tsentr KNUKiM [in Ukrainian]. 